\title{
Statement of Problem of Palliative Care Institutionalization in Modern Russia
}

\author{
V.V. Moiseev \\ Belgorod State Technological University named after V.G. \\ Shukhov, Belgorod, 308012, Russia \\ din_prof@mail.ru \\ E.K. Naberushkina \\ Moscow State University of Humanities and Economics \\ 49 Losinistrovskaya St., Moscow, 107150, Russia
}

\author{
O.A. Sudorgin \\ Moscow State University of Humanities and Economics \\ 49 Losinistrovskaya St., Moscow, 107150, Russia
}

\begin{abstract}
The article deals with conceptualization of palliative care as a social institution and the need to incorporate it into the system of national policy of the Russian Federation. A review of theoretical concepts related to palliative care showed that research works are scattered across the fields of medicine, law, philosophy, social work, gerontology and social policy, but a transdisciplinary conceptual model of palliative care, which presents both fundamental concepts and particular issues of institutionalization and professionalization of palliative care in detail, has not yet been established. The article sets key tasks, the solution of which will contribute to the formation of the institute of palliative care, performing the function of ensuring a better quality of life for terminal patients and their families.
\end{abstract} life

Keywords—palliative care, social institution, hospice, quality of

\section{INTRODUCTION}

One of the challenges determined by demographic dynamics and the request of civil society to humanize social institutions for a better quality of life for a person at any stage of his life is the lack of a clear national concept of palliative care today. The medical sciences, the sociology of medicine, the theory of social work, social gerontology, a number of paramedical scientific fields contain the formulation of the problem of ethics, methodology and value of palliative care, but neither the conceptual logic, nor any methodology of palliative care are not presented in the domestic scientific field, there is no paradigm which might be the basis of national palliative care policy. Linking together the interests of various stakeholders through the achievement of public consensus provides the basis for positioning palliative care as an institution working to increase trust in government and humanize society.

Not a single scientifically based statistical tool has been created for people needing palliative care yet. The World Health Organization records that every year around 20 million

The paper has been prepared with the financial support of the Russian Foundation for Basic Research in the framework of the grant "Integration of the Institute of Palliative Care into the National Policy of the Russian Federation” № 19-011-31181.

The article has been prepared with financial support of RFBR (project $N$ 18-011-00290 “Urban Well-Being of Disability”) people in the world need palliative care, and according to approximate data not less people need palliative care during their last year of life. Thus, the total number of people who need palliative care annually is about 40 million. The majority of those in need of palliative care live in low- and middleincome countries, mostly elderly people (age over 60), and about $6 \%$ are children .

\section{Purpose AND Questions OF RESEARCH}

The ambiguity of deontology of the final stage of human life can be seen in the difference in views that have developed in the socio-philosophical tradition on the conditionality of human existence. Subject palliative care is rooted in philosophy and philosophical thanatology. The existential philosophy of F. Nietzsche, A. Schopenhauer, K. Jaspers, M. Heidegger, J.P. Sartre caused a resonance in the array of modern socio-cultural thought, having a huge impact on the development of culture and civilization as a whole. Socrates, Plato, Augustine, and later B. Pascal, S. Kierkegaard made the person's attitude to death a subject of special analysis. In Plato and Aristotle's works the life of a person belongs to the society, and the subject of ending the life of "extra people" finds approval, at the same time the society condemns suicide. Medieval social philosophy, represented by Thomas Aquinas or Augustine asserts the identity of human life to God and the primacy of faith over reason, including in solving the problems of death and the process of dying. The third tradition began to take shape in the Renaissance and was developed in the Age of Enlightenment, where human life became the choice of the person himself. The philosophy of the life of $\mathrm{M}$. Scheller and M. Heidegger from a phenomenological position explains how the life of an individual determines the entire structure of his consciousness and his activity.

Among the most fundamental modern social and philosophical areas that deal with the themes of life and death are: cultural and historical, presented by the works of $\mathrm{P}$. Ariès, I. Linderberg; hermeneutic - in the works of M. Bakhtin and M. Uvarov; semiotic - presented by M. Foucault, J. Baudrillard, J. Derrida; psychoanalytical - by S. Freud and J. Lacan; and 
clinical - presented by S. Groff and L. Watson, N. Petrov, E. Kübler-Ross [1]. Although philosophers and psychologists were deeply interested in the topic of life and death, the mature perspective of the final stage of human life is a derivative of human rights ideology that affirms the ethical principles of respect for an individual in a situation of dying and death, as well as the result of the development of social work methodology and practice. In 1947 social worker and nurse Cecilia Saunders began to conduct systematic research in the treatment of chronic pain, and in 1967 organized the first hospice of modern type in the world in the London suburb of St. Christopher's shelter [2].

The concept of "palliative care" was first used by Canadian doctor Balfour Mount, and the ethical foundations of caring for dying patients are represented by the works of Jeanne Garnier, who laid the foundations for general patient care and also for care for families which suffered a heavy loss; and further palliative care principles were developed by R. Becker [3]. In the second half of the XX century there was a significant increase in attention to the problem of dying and death, both from physicians and scientists working in the humanities. The topic of control over death in 1955 was highlighted in detail by J. Fletcher, who talked about this in the socio-theological discourse as the basis of human dignity [4]. A few years later there appeared works of a legal nature (G. Williams) in which the legal aspects of the final stage of a person's life were discussed [5].

Socio-anthropological interpretation of the meaning of death were described in the works of $\mathrm{H}$. Feifel[6], and in the culturological discourse J. Mitford [7] revealed the theme of departure from life, paying particular attention to burial customs. Psychological aspects of the problems of dying patients were revealed in the works of psychiatrists and physicians, in particular, in 1967, Hinton's monograph "Dying" [8] was published. In the activities of public organizations, the topic of palliative care was represented by the emerging funds to assist terminal patients.

The greatest impact on palliative medicine had the work of Elizabeth Kübler-Ross “On Death and Dying,” [9] in which palliative care is presented as a complex interdisciplinary problem. In 1976 Robert Veatch analyzed the ethical side of interaction with terminal patients within the emerging direction of bioethics [10]; two years later, C. Garfield's work on psychosocial support for the dying patient appeared in the framework of medical psychology [11].

In the domestic scientific field, the problems of dying patients became the subject of analysis in the 1980s, but the major part of this literature dates back to the 1990s. Mostly this topic was present in the medical literature on cancer patients, as well as issues of surgical deontology. Medical publications on euthanasia have traditionally justified a sharply negative attitude towards it, but a number of legal publications (Malein N.S.) set forth a view of euthanasia as a voluntary decision of a terminal patient and formulated legal requirements for such social practice [12]. In the 1990s, the first sociological studies appeared that found that more than half of Moscow doctors had never thought about euthanasia or found it difficult to give answers to questions about euthanasia in general, and about
$35 \%$ of those who answered that euthanasia was acceptable in some situations, despite some officially proclaimed legal and ethical standards. Today, according to VTsIOM (2019), 81\% of Russians are against voluntary euthanasia.

It should be noted that, in general, in domestic science the palliative theme was poorly developed, and medical practice had few opportunities for effective pain control. The development of drug therapy in the 1950s, combined with greater understanding of psychological and spiritual needs of dying patients, laid the foundation for development of palliative care services. The principles of palliative care began to be clarified, and the philosophy of the hospice movement became known in our country mainly due to the work of Robert J. Twicross and David R. Frampton [13], where problems of a conscious attitude towards cancer were raised. For the first time in the domestic literature appeared a brief statement of religious and ethical issues of palliative care.

The current state of the scientific methodology of palliative care shows that it is mostly developed in the field of medicine (but not fully), to a certain extent it is presented in the field of social work methodology, there are separate scientific developments in the framework of social gerontology, sociology of social problems and sociology of medicine.

The legal context of the problem of a dying patient is considered by Yu.Sergeev, G.Stetsenko, and A.K. Khetagurova, N.V.Ekkert, V.Z.Kucherenko and V.I. Semenov write about ways to reform the health care system [14].

Palliative care for incurable patients in the social work system is revealed by T.B. Firsov, E.I. Kholostova, B.Yu. Shapiro and V.N. Yarskaya [15]. Prospects for the development of palliative care in the Russian Federation are discussed by G.A. Novikov, V.I. Chissov and S.V. Rudoy [16]. Organizational mechanisms of interaction in provision of palliative care are described by V.Yu. Kulkova [17]; theoretical aspects of palliative care in hospice have been studied by N.F. Divitsyna, A.B. Dubrovich, I.N. Zakatova and G.A. Makeev [18]; the problems of medical confidentiality and ethics were investigated by V.I. Chissov and S.L. Daryalova [19].

Within the framework of clinical psychology and understanding psychotherapy, F.E. Vasilyuk [20] analyzes palliative care, and bioethical issues are discussed in the context of the terminal stage of human life in the works of $\mathrm{V}$. Millionshchikova, A. Ivanyushkin and E. Mihailova [21]. As a special interdisciplinary scientific field, represented by the work of physicians, philosophers, gerontologists and sociologists, the scientific direction of thanatology continues to be formed.

At the same time, the analysis of a significant amount of work related to the problems of palliative care and in general the themes of the last stage of a person's life showed that the subject of palliative care is medicalized, and the interaction with the terminal patient is still at the mercy of medicine. Fundamental sociological works within the framework of the problem of palliative care are practically absent, and the issues of organization and management of the palliative care system rarely enter the field of socio-political discourse and only do so 
due to tremendous efforts of public organizations (V.F. Nitsevich) [22].

\section{CONCLUSION}

In this regard, today there is an urgent need to institutionalize palliative care, which is caused by objectively existing risks: firstly, the situation of people suffering from an incurable disease is exacerbated by pushing their problems into a private family, less often into a charitable sphere, also by the lack or insufficiency of helping medical and social institutions; secondly, the dying patients today are marked mainly as patients of the health system, for which this category of patients is peripheral, since their care is mainly reduced to one function - the function of anesthesia and nursing care. At the same time, it is obvious that medicalization not only narrows the understanding of palliative care, but leaves behind such important tasks as social, psychological, spiritual and legal support in order to improve and maintain the quality of life of both patients and their families; thirdly, attempts to establish partnerships between departments and the main aid structures that are able to effectively solve the problems of palliative care have not been successful. There is a range of problems associated with the storage policy and the exclusion of people at the terminal stage, with control by the Federal Drug Control Service, with differences in the perception of narcotic analgesics (in particular, there happen cases of resistance to their use by religious ministers). A person who needs palliative care is often the object of manipulation, is infantilized by society, he or she is not perceived as an active subject in the decision-making process regarding his own life.

The state itself and the state system of intervention in the task of assisting dying patients is in its infancy, although the amendments to the Federal Law of 21 November 2011 N 323 "On the basis of citizens' health protection in the Russian Federation" [23] have been adopted, a single document defining the entire system responsibility and coordination of the institution of palliative care in general is still required. At the same time, scientific, methodological and public efforts are needed to demedicalize palliative care and bring to the fore the very person who is at the end of life. The current practice of helping people in a terminal state does not see the person himself with his individual needs, the specifics of his family situation and the thresholds for sensitivity to painkillers. The order of the Ministry of Health №330 [24] prescribed doses of narcotic drugs that must be respected in any case, but sometimes these standards do not help to relieve pain properly. The only criterion for sufficient anesthesia in foreign countries is to apply it until the moment of the cessation of pain comes, as to domestic practice, it can only be applied until the dose of the drug exceeds the norms of the law. And finally, the question is posed that the state should ensure a decent life for all citizens, but social institutions designed to provide care to patients whose days are numbered today are unable to exist in a system created without a real economic basis.

The legal uncertainty of the palliative care system entails problems associated with the professionalization of palliative care in Russia. Today, scientific specialization in the profile of palliative care exists only in the form of retraining courses and additional education, the training system in general has not been built yet. In the legislative and economic spheres the balance between the medical and social aspects of the work of palliative services has not been regulated.

A sociocultural analysis of the problem shows that among the majority of Russians there is a perception of palliative care as an exclusively oncological medical specialty, there is a fear of a detailed discussion of the topic of death in public consciousness. The mythologization of ideas about palliative care and the final stage of human life continue. The logic of palliative care in the sociocultural field is exclusively related to the procedure for facilitating the process of dying, while a civilized approach requires the conceptualization of palliative care in the logic of normalizing the life of an incurable person and his family members.

Consequently, the development of palliative care discourse in the transdisciplinary logic of political and social sciences is a necessary approach, the applied effects of which are aimed at restoring economic growth and strengthening social cohesion; it is an investment in trust management in the context of public sector reforms. Today it is necessary to set the task of justifying palliative care as a social institution for further integration into the national policy of the Russian Federation. In an interdisciplinary context, evidence-based scientific approaches and methodologies are needed to evaluate the measures and quality of palliative care. Lack of political recognition and established state policy in the field of palliative care development, lack of sustaina.

On March 17, 2019, the law on palliative care entered into force in Russia. It includes not only the medical component, but also the psychological, spiritual and social support of the patient [25].

\section{REFERENCES}

[1] Ariès P. L'Homme devant la mort. Translation from French. M "Progress-Akademia", 1992, 527 p; Linderberg I. Extermination of the sick and German psychiatry. Review of psychiatry and medical psychology after V.M. Bekhterev. - 1992, Vol. 4, Pp.138-142; KüblerRoss E. On death and dying/ Translation from English. Kiev: "Sofia", 2001, 320p; Petrov N.N. Surgical deontology issues, Ed. 5, L. Medgiz, 1956, 63p. and etc.

[2] Cecilia Sanders - the mother of hospices. - URL: https://www.pravmir.ru/sesiliya-sanders-mat-hospisov/

[3] Becker, R. Working principles of palliative care / R. Becker [et al.] // European Journal of Palliative Care. - 2010. - Vol. 16. - P. 94-97.

[4] Fletcher J. Morals and medicine. M., 1955

[5] Williams G.L. Homicide and the Supernatural // The Law Quarterly/ Review, 1949, Vol. 65, (260), Pp. 491-503.

[6] Feifel H. The Meaing of Death. N.-Y., 1959.

[7] Mitford J. The American Way of Death, N.-Y., 2004. 296 p.

[8] Hinton. J. Dying. Penguin Books, 1967.

[9] Kübler-Ross E. On death and dying/ Translation from English, Kiev, "Sofia”, 2001, 320p.

[10] Veatch R.M. A theory of medical ethics - New York: Basic Books, 1981

[11] Garfield Ch. A. Psychosocial care of the dying patient, N.-Y: McGraw. Hill, 1978.

[12] Malein N.S. About medical secrecy // Owls. State and law. M., 1981. No 8. P. 79-86 
[13] Robert J. Twicross, David R. Frampton "Introduction to Palliative Care", Sobell Publication, 1992. - URL: http://medpsy.ru/society/society001.php.

[14] Semenov V.I. The experience of using ketorodac tromethamine in the complex treatment of postoperative pain syndrome in oncology // Palliative medicine and rehabilitation, 2004, №2. P.106-107

[15] Firsov, M. V., Shapiro, B. Yu. Psychology of social work: content and methods of psychosocial practice: study guide for universities / M Firsov, B. Yu. Shapiro. - 6th ed., Pererab. and add. - Moscow: Yurait Publishing House, 2019. - 390 p.

[16] Firsov, M. V., Shapiro, B. Yu. Psychology of social work: content and methods of psychosocial practice: study guide for universities, 6th ed., Pererab. and add. Moscow: Yurait Publishing House, 2019, 390 p.

[17] Kulkova V.Yu., Mironenko N.V., Rudakova O.V. Organizational and informational support of the activities of SO NPOs in the Russian Federation and the Republic of Tatarstan. Vestnik Orel GIET, 2012, Vol. 2 (20). Pp. 165-171.

[18] Zakatova I.N. The basis of medical and social care in hospice. M.: Academy, 2014, 345 p.

[19] Divitsyna N.F. Features of palliative patients in hospice. Rostov-on-Don Phoenix, 2014,198 p.; Dubrovich A.B. The content of palliative patients in hospice. M.: Vlados, 2012,102 p.
[20] Vasilyuk F.E. Survive the grief // The human in man. M.: Politizdat, 1991. - p. 230-247.

[21] Millionshchikov, V.V., Gnezdilov, A.B., Ivanyushkin, A.Y., Home for Life. Man, 1994, Vol. 5. pp. 116-121.

[22] V.F. Nitsevich. Analysis of the organization and experience of publicprivate partnership in Russia // Srednerussky Bulletin of General Sciences, 2013, Vol. 4, Pp.225-231

[23] Federal Law of 21 November 2011 N 323 "On the basis of citizens' health protection in the Russian Federation". Srednerussky Bulletin of General Sciences, 2013, No. 4, S.225-231available at http://kremlin.ru/acts/bank/34333

[24] Order of the Ministry of Health of the Russian Federation of $12.11 .97 \mathrm{~N}$ 330 (ed. of 06.26.2008) "On measures to improve the accounting, storage, prescription and use of narcotic drugs and psychotropic substances" available at https: //zakonbase.ru/content/base/8495

[25] Palliative Care Act entered into force/ - URL: https://rg.ru/2019/03/17/zakon-o-palliativnoj-pomoshchi-vstupil-vsilu.html. 